\title{
Electron Microprobe
}

National Cancer Institute

\section{Source}

National Cancer Institute. Electron Microprobe. NCI Thesaurus. Code C78817.

An instrument that focuses an electron beam at a sample and measures the

wavelengths and intensities of the $\mathrm{X}$-rays emitted by the elements in the material. 